\title{
Effect of Plant Residues on Chemical Properties of Soil and Nutrient Uptake of Soybean
}

\author{
S. Ravi ${ }^{1^{*}}$, R.L. Jadhav ${ }^{2}$, Sidramappa $^{3}$ and Anand Kamble ${ }^{2}$ \\ ${ }^{1}$ Deaprtment of Soil Science and Agricultural Chemistry, \\ ${ }^{2}$ Department of Agronomy, KVK, Bidar, UAS, Raichur, Karnataka, India \\ ${ }^{3}$ Department of Genetics and Plant Breeding, ARS, Bidar, Karnataka, India \\ *Corresponding author
}

\section{A B S T R A C T}

\section{Keywords}

Soil, Available nutrients, $\mathrm{pH}$,

Organic carbon, Soybean.

\section{Article Info}

Accepted:

26 October 2017

Available Online:

10 December 2017
A field study was conducted during Kharif 2012 and 2013 at Krishi Vigyana Kendra, Janwada, Bidar, University of Agricultural Sciences, Raichur, Karnataka, India to study the effect of crop residues on chemical properties of soil and nutrient uptake of soybean in rainfed situation of Northern Karnataka. Results revealed that, application of RDF (40:80:25 NPK kg/ha $+12 \mathrm{~kg} \mathrm{ZnSO} / \mathrm{ha}+20 \mathrm{~kg}$ sulphur/ha) + plant residues at 3.0 tonnes/ha recorded significantly $(\mathrm{p}=0.05)$ higher uptake of nitrogen $(225.7 \mathrm{~kg} / \mathrm{ha})$, phosphorus $(17.0 \mathrm{~kg} / \mathrm{ha})$ and potassium $(73.5 \mathrm{~kg} / \mathrm{ha}$ ) by soybean and which was onpar with the application of RDF + plant residues at 2.25 tonnes/ha $(157.8,16.3$ and $71.3 \mathrm{~kg} / \mathrm{ha}$, respectively). Further, Application of RDF + plant residues at $0.75,1.5$ and 2.25 tonnes/ha were atpar with each other with respect to nitrogen, phosphorus and potassium uptake by the soybean. Application of RDF (40:80:25 NPK kg/ha $+12 \mathrm{~kg} \mathrm{ZnSO} / 4 \mathrm{ha}+20 \mathrm{~kg}$ sulphur/ha) + plant residues at 3.0 tonnes/ha has been increased the soil available nutrients and improves the soil fertility.

\section{Introduction}

Soybean [Glycine max (L.) Merrill] in India is cultivated over an area of 9.4 million ha with production of 9.6 million tons and is known as "Golden Bean" of 20th century. Though soybean is a legume crop, yet it is widely used as an oilseed. It is now occupying first place among all the oilseed crops in India followed by rapeseed mustard and groundnut, respectively. It grows in varied agro-climatic conditions. Due to its world- wide popularity, the international trade of soybean has spread globally. Soybean possesses a very high nutritional value and is the richest, cheapest and easiest source of the best quality proteins
(40 \%) and oil (20 \%) having a vast multiplicity of uses as food and industrial products (Anon. 2016).

Producers have expressed concerns about production practices where high levels of crop residue are present on the soil surface. These concerns include wetter soil and lower soil temperatures delaying planting and retarding plant development during early vegetative growth, and less uniform germination and emergence using planting equipment that cannot operate adequately in the residue. By the reproductive growth stage, however, 
vegetative growth of crops under no till management can catch up to the growth of crops under tilled management (Klocke et al., 1985).

Another benefit of crop residue is that it reduces the energy of water droplets impacting the soil surface, thereby reducing the detachment of fine soil particles that tend to seal the surface and lead to crust formation. This sealing and crusting process can be enhanced by subsequent soil surface drying, and it reduces infiltration and promotes runoff because precipitation or irrigation rates may be greater than the rates at which the soil is able to absorb water.

Residue may increase surface storage of rain or irrigation water. In addition, it slows the velocity of runoff water across the soil surface, allowing more time for infiltration (Steiner, 1994).

Bidar District of Karnataka (India) is dominated by red lateritic and medium to deep black soils and these soils are poor in soil fertility due to deficiency of secondary and micronutrients. Soybean is one of the important oil seed crop and it is being grown in an area of 95,000 ha with a production of 33,250 thousand tonnes with an average productivity of $725 \mathrm{~kg} / \mathrm{ha}$. Since, the yields are low as compared to state average (950 $\mathrm{Kg} / \mathrm{ha})$.

Intensive cropping, indiscriminate use of fertilizers and limited use of organic matter and plant residues are the reasons for limits soybean yield. However, very meager information is available on effect of plant residues on chemical properties of soil and nutrient uptake of soybean. Hence a field experiment was conducted to investigate the effect of plant residues on chemical properties of soil and nutrient uptake of soybean in Northern Karnataka.

\section{Materials and Methods}

An experiment was taken during Kharif 2012 and 2013 at Krishi Vigyana Kendra (KVK), Janwada, Bidar, University of Agricultural Sciences, Raichur, Karnataka, India. The soil of the experimental field was clay loam, slightly saline $(\mathrm{pH} 8.36)$, high in organic carbon $(0.53 \%)$, available nitrogen $(268.0 \mathrm{~kg}$ $\mathrm{N} / \mathrm{ha}$ ), phosphorus (30.6 $\left.\mathrm{kg} \mathrm{P}_{2} \mathrm{O}_{5} / \mathrm{ha}\right)$ and potassium (423 $\mathrm{kg} \mathrm{K} \mathrm{K}_{2} \mathrm{O} / \mathrm{ha}$ ). The experiment was comprises of six treatments viz., $\mathrm{T}_{1}$ : Absolute Control, $\mathrm{T}_{2}$ : RDF (40:85:25 kg NPK + $12 \mathrm{~kg} \mathrm{ZnSO}+20 \mathrm{~kg} \mathrm{Sulphur} / \mathrm{ha}), \mathrm{T}_{3}$ : RDF + Plant residue at 0.75 tonnes/ha, $\mathrm{T}_{4}: \mathrm{RDF}+$ Plant residue at 1.50 tonnes/ha, $\mathrm{T}_{5}: \mathrm{RDF}+$ Plant residue at 2.25 tonnes/ha and $\mathrm{T}_{6}: \mathrm{RDF}+$ Plant residue at 3.0 tonnes/ha. The experiment was laid out in randomized complete block design with four replications. Soybean variety JS 335 was grown at a row spacing of $45 \mathrm{~cm}$. Crop received recommended dose of nutrients @ 40:80:25: kg N: $\mathrm{P}_{2} \mathrm{O}_{5}: \mathrm{K}_{2} \mathrm{O}$ per ha through urea, di-ammonium phosphate and muriate of potash, respectively. Sulphur and Zinc sulphate were applied as per treatment details through gypsum (18\% S) and Zinc sulphate, respectively. Soybean seed were inoculated with Bradyrhizobium japonicum culture @5 $\mathrm{g}$ per $\mathrm{kg}$ seed. The crop residues were applied as per the treatment after the germination of crop. The rainfall received during kharif 2012 and 2013 was $850 \mathrm{~mm}$ and $940 \mathrm{~mm}$, respectively. Other crop management practices were performed as per recommended package of practices. The plant samples were collected for recording dry matter production and estimation of nutrient concentration. The plant samples used for recording dry matter production at harvest were used for analyzing nutrients present in the plant. After recording the dry weight from each treatment the samples were powdered in a micro Willey mill. The samples were analyzed for concentration of different nutrients $(\mathrm{N}, \mathrm{P}$ and $\mathrm{K})$ present in the plant 
parts. Nitrogen Phosphorus and potassium content of stover was estimated by modified micro-Kjeldhal's method, Vanadomolybdo phosphoric acid yellow colour method and absorbance of the solution was recorded at $430 \mathrm{~nm}$ using spectrophotometer and flame photometer method, respectively (Jackson, 1967).

Available nitrogen in soil was determined by alkaline permanganate method as outlined by Subbiah and Asija (1959). Available phosphorus in soil was determined by Bray's method as outlined by Jackson (1967). Available potassium in soil was determined by neutral normal ammonium acetate solution using flame photometer as outlined by Jackson (1967). MSTAT was used for statistical analysis of data and means were separated using critical difference (CD) at $\mathrm{p}=0.05$. The data on weeds were transformed by square root transformation before being subjected to ANOVA (Gomez and Gomez, 1984).

\section{Results and Discussion}

\section{Effect of plant residues on yield and yield parameters of soybean}

Results revealed that, Application of RDF (40:80:25 NPK kg/ha + $12 \mathrm{~kg} \mathrm{ZnSO} /$ ha+ 20 $\mathrm{kg}$ sulphur/ha) + plant residues at 3.0 tonnes/ha recorded significantly $(\mathrm{p}=0.05)$ higher haulm and seed yield (3007 and 2269 $\mathrm{kg} / \mathrm{ha}$, respectively) and which was onpar with the application of RDF + plant residues at 2.25 tonnes/ha (2839 and $2136 \mathrm{~kg} / \mathrm{ha}$, respectively).

Further, Application of RDF + plant residues at $0.75,1.5$ and 2.25 tonnes/ha were atpar with each other with respect to haulm and seed yield (Table 1). This might be due to the favourable role of nutrients and moisture storage due to mulching with plant residues in nodulation and seed formation process. The results are in consistent with the findings of Saxena and Nainwal (2010) who reported that seed and haulm yield increased significantly with incremental dose of sulphur and boron application.

Application of crop residues on soil may conserve the soil moisture content and reduces the weed population. Therefore, the yield of soybean has been drastically increased. Plant residues acts as a mulching so that, it favours the plant growth.

\section{Effect of plant residues on nutrients uptake of soybean}

Nitrogen, phosphorus and potassium uptake by soybean was significantly $(p=0.05)$ increased with different rate of application of plant residues along with RDF (Table 1). Maximum uptake of nitrogen $(225.7 \mathrm{~kg} / \mathrm{ha})$, phosphorus $(17.0 \mathrm{~kg} / \mathrm{ha})$ and potassium $(73.5$ $\mathrm{kg} / \mathrm{ha}$ ) by soybean was observed in the treatment with the application of RDF + Plant residues at 3.0 tonnes/ha and which was onpar with the application of RDF + plant residues at 2.25 tonnes/ha $(157.8,16.3$ and $71.3 \mathrm{~kg} / \mathrm{ha}$, respectively) compared to other treatments. The control treatment recorded the lowest uptake of nitrogen, phosphorus and potassium. Similar findings are also reported by Ganeshamurthy (1996) who reported that application of sulphur significantly increased the sulphur uptake in soybean.

\section{Effect on chemical properties of soil}

The data on chemical properties of soil is presented in Table 2. Results revealed that, among different rate of plant residue application along with recommended dose of fertilizer was significantly not differed with respect to $\mathrm{pH}$, electrical conductivity (EC) and organic carbon (OC) content in soil after harvest of soybean. 
Table.1 Effect of plant residues on yield and nutrients uptake of soybean

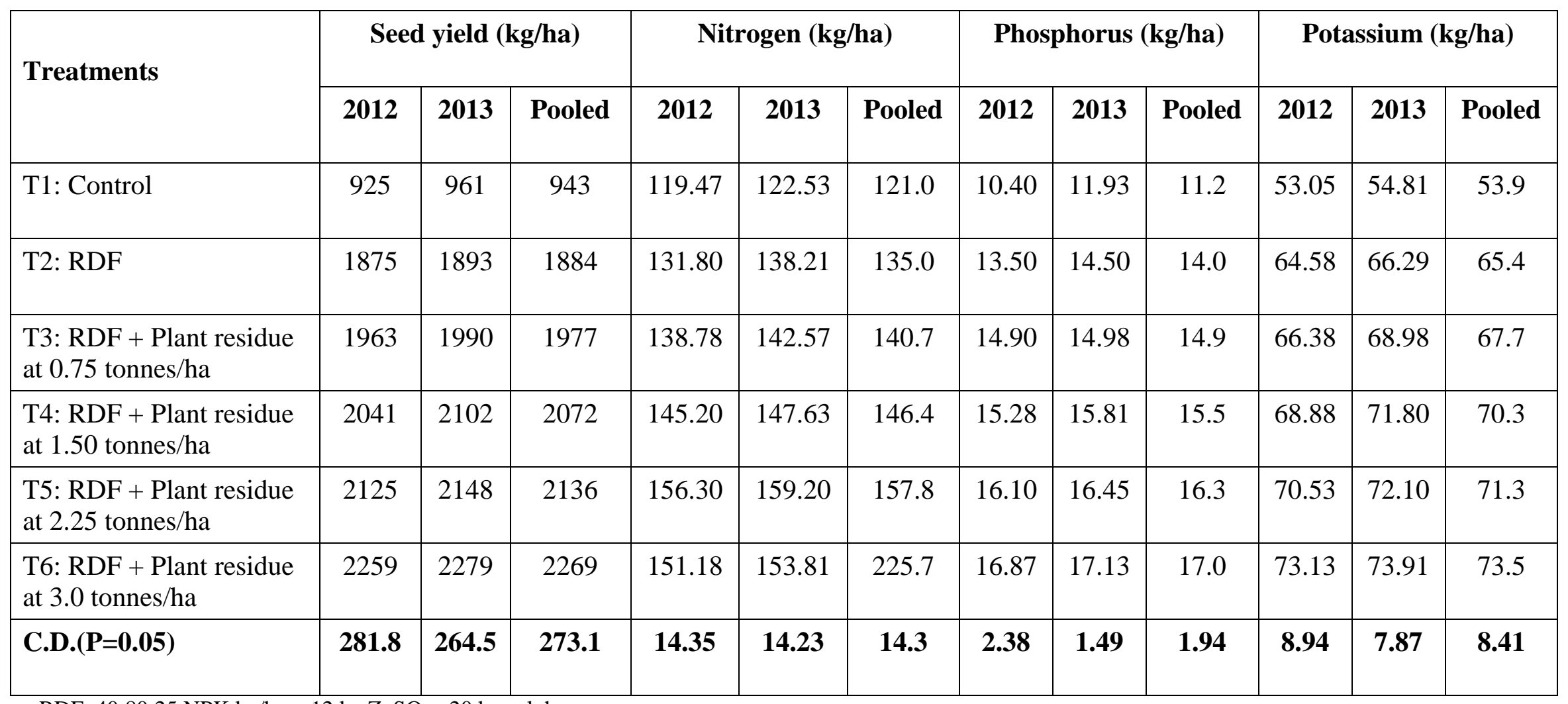

RDF: 40:80:25 NPK kg/ha + $12 \mathrm{~kg} \mathrm{ZnSO}_{4}+20 \mathrm{~kg}$ sulphur 
Table.2 Effect of plant residues on chemical properties of soil after harvest of soybean

\begin{tabular}{|c|c|c|c|c|c|c|c|c|c|}
\hline \multirow[b]{2}{*}{ Treatments } & \multicolumn{3}{|c|}{ pH } & \multicolumn{3}{|c|}{$E C(d S / m)$} & \multicolumn{3}{|c|}{$\mathrm{OC}(\%)$} \\
\hline & 2012 & 2013 & Pooled & 2012 & 2013 & Pooled & 2012 & 2013 & Pooled \\
\hline T1: Control & 8.35 & 8.36 & 8.35 & 0.24 & 0.28 & 0.26 & 0.51 & 0.50 & 0.51 \\
\hline $\begin{array}{l}\text { T3: RDF + Plant residue at } 0.75 \\
\text { tonnes/ha }\end{array}$ & 8.37 & 8.39 & 8.38 & 0.29 & 0.33 & 0.31 & 0.54 & 0.54 & 0.54 \\
\hline $\begin{array}{l}\text { T4: RDF + Plant residue at } 1.50 \\
\text { tonnes/ha }\end{array}$ & 8.37 & 8.40 & 8.38 & 0.31 & 0.35 & 0.33 & 0.55 & 0.56 & 0.56 \\
\hline $\begin{array}{l}\mathrm{T} 5: \mathrm{RDF}+\text { Plant residue at } 2.25 \\
\text { tonnes/ha }\end{array}$ & 8.39 & 8.41 & 8.40 & 0.33 & 0.37 & 0.35 & 0.55 & 0.56 & 0.56 \\
\hline T6: RDF + Plant residue at 3.0 tonnes/ha & 8.39 & 8.41 & 8.40 & 0.33 & 0.37 & 0.35 & 0.56 & 0.57 & 0.57 \\
\hline C.D. $(P=0.05)$ & NS & NS & NS & NS & NS & NS & NS & NS & NS \\
\hline
\end{tabular}

RDF: 40:80:25 NPK kg/ha + $12 \mathrm{~kg} \mathrm{ZnSO}_{4}+20 \mathrm{~kg}$ sulphur

Table.3 Effect of plant residues on soil available nutrients after harvest of soybean

\begin{tabular}{|c|c|c|c|c|c|c|c|c|c|}
\hline \multirow{2}{*}{ Treatments } & \multicolumn{3}{|c|}{ Nitrogen (kg/ha) } & \multicolumn{3}{|c|}{$\mathrm{P}_{2} \mathrm{O}_{5}(\mathrm{~kg} / \mathrm{ha})$} & \multicolumn{3}{|c|}{$\mathrm{K}_{2} \mathrm{O}(\mathrm{kg} / \mathrm{ha})$} \\
\hline & 2012 & 2013 & Pooled & 2012 & 2013 & Pooled & 2012 & 2013 & Pooled \\
\hline T1: Control & 232 & 236 & 234 & 24.0 & 25.0 & 24.5 & 493 & 341 & 417 \\
\hline T2: RDF & 273 & 278 & 276 & 27.2 & 29.1 & 28.2 & 518 & 373 & 445 \\
\hline T3: RDF + Plant residue at 0.75 tonnes/ha & 280 & 285 & 283 & 31.4 & 33.2 & 32.3 & 530 & 385 & 457 \\
\hline T4: RDF + Plant residue at 1.50 tonnes/ha & 287 & 290 & 289 & 36.6 & 38.1 & 37.4 & 534 & 391 & 463 \\
\hline T5: RDF + Plant residue at 2.25 tonnes/ha & 291 & 296 & 293 & 43.7 & 44.9 & 44.3 & 548 & 402 & 475 \\
\hline T6: RDF + Plant residue at 3.0 tonnes/ha & 299 & 304 & 302 & 49.6 & 52.2 & 50.9 & 550 & 405 & 478 \\
\hline C.D. $(P=0.05)$ & 26.5 & 22.9 & 24.9 & 3.25 & 5.41 & 4.33 & NS & NS & NS \\
\hline
\end{tabular}

RDF: 40:80:25 NPK kg/ha + $12 \mathrm{~kg} \mathrm{ZnSO}+20 \mathrm{~kg}$ sulphur 
Effect on soil available nutrients after harvest of soybean

Available nitrogen, phosphorus and potassium in soil was significantly $(p=0.05)$ increased with different rate of application of plant residues level (Table 3). Maximum availability of nitrogen $(302 \mathrm{~kg} / \mathrm{ha})$, phosphorus $(50.9 \mathrm{~kg} / \mathrm{ha})$ and potassium $(478.0$ $\mathrm{kg} / \mathrm{ha}$ ) in soil after harvest of soybean was observed in the treatment with the application of RDF + plant residues at 3.0 tonnes/ha and which was on par with the application of RDF + plant residues at 2.25 tonnes/ha (293.0, 44.3 and $475 \mathrm{~kg} / \mathrm{ha}$, respectively) compared to other treatments. The control treatment recorded significantly lower available nutrients in soil. These results are conformity with the findings of Meena et al., (2011).

Results indicated that, application of RDF (40:80:25 NPK kg/ha + $12 \mathrm{~kg} \mathrm{ZnSO}_{4} / \mathrm{ha}+20$ $\mathrm{kg}$ sulphur/ha) + plant residues at 2.25 or 3.0 tonnes/ha was improved the soil nutrient status and increased the seed yield of soybean.

\section{References}

Anonymous. 2016. Director's Report and Summary Tables of Experiments (20142015), All India Coordinated Research Project on Soybean, Indore.
Ganeshamurthy A N. 1996. Effect of sulphur application on seed and oil yield of Soybean. Journal of the Indian Society of Soil Science 44(2): 290-4.

Gomez, K.A. and A.A. Gomez, (1984). Statistical procedures for agricultural research (2 edn.). John Wiley and sons, New York, 680p.

Jackson, M.L., 1967, Soil Chemical Analysis. Prentice Hall of India Pvt. Ltd., New Delhi, pp. 183-192.

Klocke, N. L., D. F. Heermann, and H. R. Duke. 1985. Measurement of evaporation and transpiration with lysimeters. Trans. ASAE 28(1): 183189, 192.

Meena D S, Ram B and Tetarwal J P. 2011. Productivity, quality and profitability of soybean (Glycine max L.) as influenced by sulphur and boron nutrition. Soybean Research 9: 103-108.

Saxena S C and Nainwal R C. 2010. Effect of sulphur and boron nutrition on yield, yield attributes and economics of soybean. Soybean Research, 8: 7-12.

Steiner, J. L. 1994. Crop residue effects on water conservation. In Managing Agricultural Residues, 41-76. P. W. Unger, ed. Boca Raton, Fla.: CRC Press.

Subbiah, B.V. and Asija, C.L., 1959. A rapid procedure for estimation of available nitrogen in soils. Curr. Sci., 25:259-260

\section{How to cite this article:}

Ravi, S., R.L. Jadhav, Sidramappa and Anand Kamble. 2017. Effect of Plant Residues on Chemical Properties of Soil and Nutrient Uptake of Soybean. Int.J.Curr.Microbiol.App.Sci. 6(12): 3484-3489. doi: https://doi.org/10.20546/ijcmas.2017.612.405 